\title{
Investigation of Vitiated Species on the Effect of Scramjet Combustion Using Fuel of Hydrogen or Ethylene
}

\author{
Weiqiang $\mathrm{Li}^{1}$, Wenyan Song ${ }^{1}$ \& Jianping $\mathrm{Li}^{1}$ \\ ${ }^{1}$ School of Power and Energy, Northwestern Polytechnical University, China \\ Correspondence: Weiqiang Li, School of Power and Energy, Northwestern Polytechnical University, Shaanxi, \\ Xi'an 710072, China. Tel: 86-138-9180-8380. E-mail: 345949526@qq.com
}

Received: March 20, 2012

Accepted: April 5, $2012 \quad$ Online Published: May 1, 2012

doi:10.5539/mas.v6n5p73

URL: http://dx.doi.org/10.5539/mas.v6n5p73

\begin{abstract}
In ground test of the scramjet, the air is heated by burning oxygen in oxygen-enriched air to simulate the flight enthalpy. As result, test media are contaminated by species $\left(\mathrm{H}_{2} \mathrm{O}, \mathrm{H}, \mathrm{O}, \mathrm{OH}\right.$ and $\left.\mathrm{CO}_{2}\right)$, which are not of representative in the actual atmosphere. In the article, the high enthalpy air is simulated by used the resistance heater, meantime vitiated species is introduced to the high enthalpy air. The effect of combustion is investigated by the experiments used the fuel of hydrogen or ethylene, when the test media are contaminated by $\mathrm{H}_{2} \mathrm{O}$ and $\mathrm{CO}_{2}$. At the same time, the effect of scramjet combustion is researched by numerical simulated. The result: the effect on the wall pressure and the combustion performance is markedly when the coming flow with contamination of $\mathrm{H}_{2} \mathrm{O}$ and $\mathrm{CO}_{2}$.
\end{abstract}

Keywords: scramjet, contaminate, combustion, performance, enthalpy

\section{Introduction}

The high enthalpy gas with properties representative of those at flight conditions was simulated on the ground testing of scramjet. In general, the Mach number, temperature, pressure and species of parameters of flow were matched. The combustion heater was usually used to simulate the high enthalpy gas, with $21 \%$ mole percent of $\mathrm{O}_{2}$ at the exit of heater. As result, there were different between high gas and really air of flight because of the vitiated species introduced.

It was difficult that the high enthalpy gas was supplied with no vitiated species on the testing of scramjet. In currently, the method of air heating: 1) electric heating, 2) combustion heater, 3) storage heater, 4) shock tube heating. In these methods of air heating, the test gas could be vitiated by some certain species, such as $\mathrm{H}_{2} \mathrm{O}, \mathrm{H}, \mathrm{O}$, $\mathrm{OH}, \mathrm{CO}_{2}$ and $\mathrm{NO}$ etc. The properties of test gas would be changed by these vitiated species, which had effect on the performance of combustor.

Rogers (1986) assessed the vitiation effects of $\mathrm{NO}$ and $\mathrm{H}_{2} \mathrm{O}$ on the ignition and reaction of hydrogen. Three models of the burning process were simulated with detailed chemical kinetics. As result: the ignition was promoted by the ions of $\mathrm{H}, \mathrm{O}, \mathrm{OH}$. He demonstrated the promotion effect of $\mathrm{NO}$ and the retardation effect of $\mathrm{H}_{2} \mathrm{O}$ in the diffusion-controlled combustion.

Mitani T. et al. (1996) compared the free jet scramjet test with the fuel of hydrogen on the facility of RJTF with the heating methods of SAH or VAH. In the nozzle exit of heater, only specific heat among the all thermodynamic parameter was different. The result of test demonstrated: the ignition was promoted as VAH used, and the thrust of scramjet applied SAH was higher than VAH.

The resistive heating elements at University of Virginia was be used to investigate the effect of vitiated species of $\mathrm{H}_{2} \mathrm{O}$ and $\mathrm{CO}_{2}$ on the performance of scramjet combustor with fuel of hydrogen by McDaniel Jr. J. C. et al. (2003). To permit simulation of a combustion heated, high enthalpy facility required the addition of vitiated species and $\mathrm{O}_{2}$ (to maintain a mole fraction 21\%) to match contaminants present in a vitiated flow. At Mach number 2 of facility nozzle exit, unswept ramp injectors were in the combustor. $\mathrm{H}_{2}$ was injected at Mach 1.7 , normal to the ramp base. As researched results: (a) At a fixed fuel equivalence ratio of $0.27,5 \% \mathrm{H}_{2} \mathrm{O}$, and $5 \%$ $\mathrm{H}_{2} \mathrm{O}$ plus $2.5 \% \mathrm{CO}_{2}$, the combustor pressure distribution decreased by $10 \%$ and $12 \%$ respectively. (b) For a fuel equivalence ratio of 0.35 , the combustor operated in a dual mode with dry air, but in the supersonic mode when vitiated with $7 \% \mathrm{H}_{2} \mathrm{O}$. An approximate Rayleigh calculation for this case predicts that $71 \%$ of the measured pressure decrease with vitiation was due to thermodynamics and $29 \%$ to chemical kinetics. The results of test of 
University of Virginia demonstrated that directly extended the conclusion of vitiated air to the conditions of really flight would make to increase to the quantity of feed the fuel.

In broad, Liu ling investigated that the effect of $\mathrm{H}_{2} \mathrm{O}$ on the ground test of supersonic combustion used the arc heating element. At Mach number 2.1, the vapor was injected nine times to simulate vitiated species, the mole fraction $1.2 \%, 2.7 \%, 3.7 \%$ of the coming flow, respectively, but no oxygen was supplemented into the flow. The results indicated: the effect of $\mathrm{H}_{2} \mathrm{O}$ couldn't be ignored in certainly conditions.

In this article, the vitiated species was simulated to apply addition vitiated species to gas of nozzle exit of direct-connected resistance heated wind tunnel. The effect of vitiated species on the wall-pressure of supersonic combustor was investigated. Then CFD simulations of reacting flow field in the combustor were conducted to investigate the effect of vitiated species on the performance of supersonic combustor.

\section{System of Test and Model}

\subsection{System of Test}

The test was conducted by used the direct-connected resistance heater wind tunnel of Northwestern Polytechnical University. The power of resistance heater is $750 \mathrm{kw}$. In sure of security of direct-connected resistance heated wind tunnel, the max mass rate of coming flow wasn't lower $0.5 \mathrm{~kg} / \mathrm{s}$ by limited. The exit total temperature of the resistance heater as main component of the facility can reach about $600 \sim 1000 \mathrm{~K}$ corresponding to air flow ratio of $1.5 \sim 0.73 \mathrm{~kg}$. The facility character of the resistance heater was that clean high enthalpy may be obtained for scramjet test.

Investigated effect of vitiated species, the simply methods were to compare the results of vitiated air and clean air of test. The effect of vitiated species was simulated by addition species of $\mathrm{H}_{2} \mathrm{O}$ and $\mathrm{CO}_{2}$ into clean high enthalpy gas in mixture room, and replenishment oxygen into gas with uniformity density, temperature of flow parameter at exit of mixture room. In order to avoid addition species interfere upstream flow with a Venturitube in front of mixture room. When clean air was needed for clean air scramjet test, it was used that same the Venturitube and mixture room, only different from vitiated air test not any more $\mathrm{H}_{2} \mathrm{O}, \mathrm{CO}_{2}$ and $\mathrm{O}_{2}$ were additional. Therefore, all flow parameter were equal to compared vitiated air and clean air test, used same the facility nozzle, model combustor, and fuel/air equivalence ration.

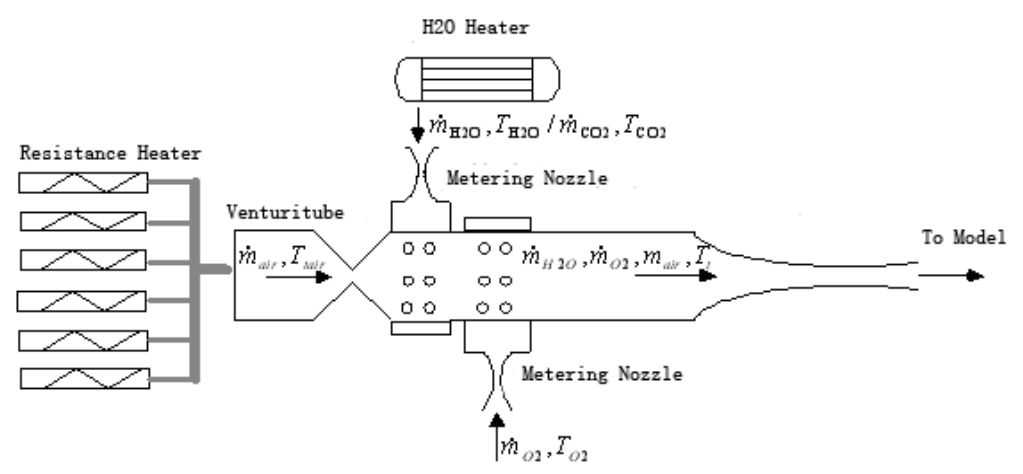

Figure 1. Production of simulated vitiated air

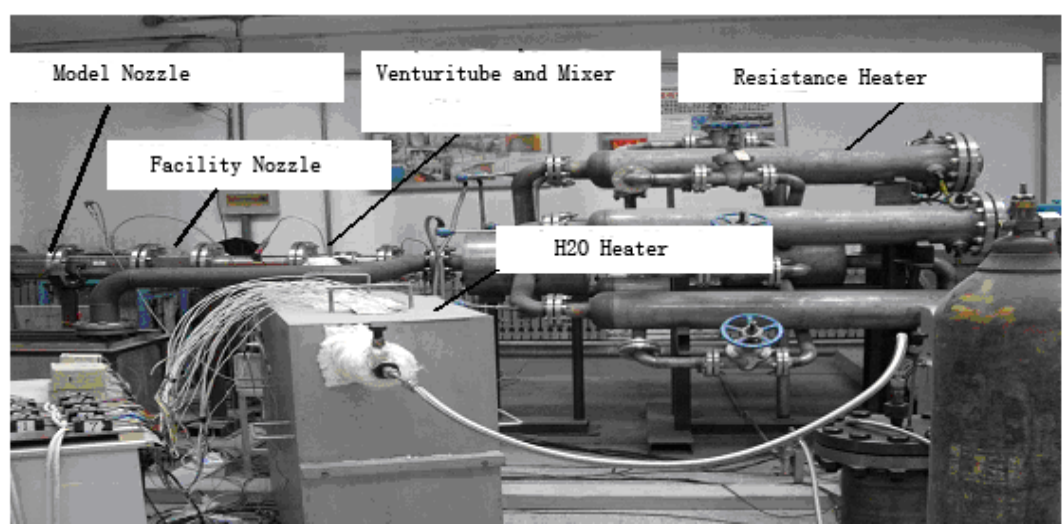

Figure 2. The picture of compared system 
Table 1. Index of specific supplied air

\begin{tabular}{ccccc}
\hline Designed parameter & electric heater & $\mathrm{H}_{2} \mathrm{O}$ heater & $\mathrm{CO}_{2}$ supplied & $\mathrm{O}_{2}$ supplied \\
\hline Mass of flow & $0.5 \sim 1.5 \mathrm{~kg} / \mathrm{s}$ & $20 \sim 150 \mathrm{~g}$ & $30 \sim 90 \mathrm{~g}$ & $7 \sim 100 \mathrm{~g}$ \\
Total temperature of flow & $600 \sim 1000 \mathrm{~K}$ & $<700 \mathrm{~K}$ & $<350 \mathrm{~K}$ & $\approx 300 \mathrm{~K}$ \\
Time of supply & $>30 \mathrm{~s}$ & $>5 \mathrm{~s}$ & $>5 \mathrm{~s}$ & $>5 \mathrm{~s}$ \\
\hline
\end{tabular}

\subsection{Model of Combustor}

A two-dimensional nozzle of nominal Mach 2.0 was used to accelerate airflow before enter into supersonic combustor model. The model of combustor used in test of compare performance of clean air and vitiated air was showed the schematic of combustor Figure 3. Total length of combustor is $770 \mathrm{~mm}$. The combustor was composed by a constant cross-section $40 \mathrm{~mm} \times 30 \mathrm{~mm}$ isolator, a single full-width cavity flame-holder, and expansion section. There was a backwards step on the up wall of isolator exit. The expansion section had 2-degree divergence up to exit on the up wall, and the width was constant. The fuels were injected perpendicularly from the injector orifices at the front and base of cavity, and the power of $12 \mathrm{~J}$ spark igniter used to ignite was located at the bottom of cavity. The flame holder of cavity and spark igniter was distributed on the down-wall of expansion section. The inlet of model combustor connected to planar facility nozzle with Mach 2 at exit. According to require different injectors and fuels (hydrogen or ethylene) could be used in test, and fuel equivalent ratio can be changed through adjusting injection pressure.

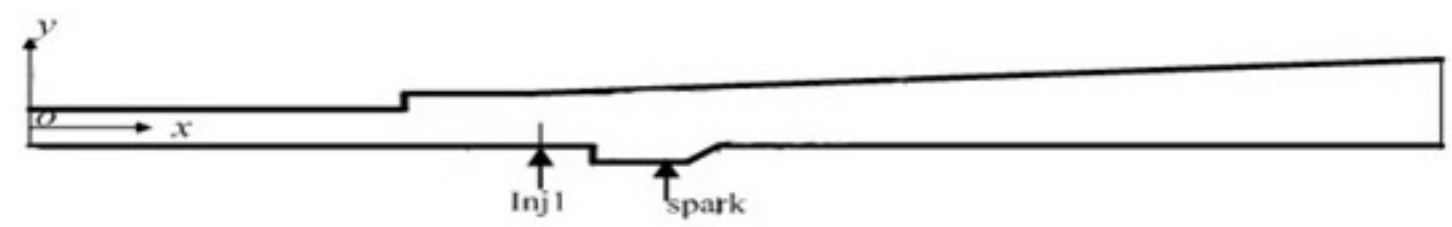

Figure 3. Model of combustor

\section{Results and Discussions}

The type test cases showed in Table 2 .

Table 2. The case of vitiated effect on the fuel hydrogen with $\mathrm{H}_{2} \mathrm{O}$ and $\mathrm{CO}_{2}$

\begin{tabular}{cccc}
\hline Case & Contaminations & $\Phi\left(\mathrm{H}_{2}\right)$ & Combustion status \\
\hline 1001 & Clean air & 0.53 & Steady \\
1002 & $7.6 \% \mathrm{H}_{2} \mathrm{O}$ & 0.52 & Steady \\
1003 & $16.6 \% \mathrm{H} 2 \mathrm{O}$ & 0.57 & Steady \\
1004 & $24.5 \% \mathrm{H} 2 \mathrm{O}$ & 0.54 & Steady \\
2001 & Clean air & 0.42 & Steady \\
2002 & $7.4 \% \mathrm{H} 2 \mathrm{O}$ & 0.42 & Steady \\
2003 & $7.4 \% \mathrm{CO} 2$ & 0.42 & Steady \\
2004 & $8 \% \mathrm{H} 2 \mathrm{O} 7.6 \% \mathrm{CO} 2$ & 0.41 & Steady \\
\hline
\end{tabular}

The combustion dimensionless up-wall and bottom pressure distribution of manifold $\mathrm{H}_{2} \mathrm{O}$ species percent vitiated air was showed in the Figure 4, which inlet of isolator was the origin coordinate. As the Figure $4 \mathrm{a}, 4 \mathrm{~b}$ showed, the combustion was steady for clean air and $\mathrm{H}_{2} \mathrm{O}$ species vitiated air. The highest wall pressure was clean air. 


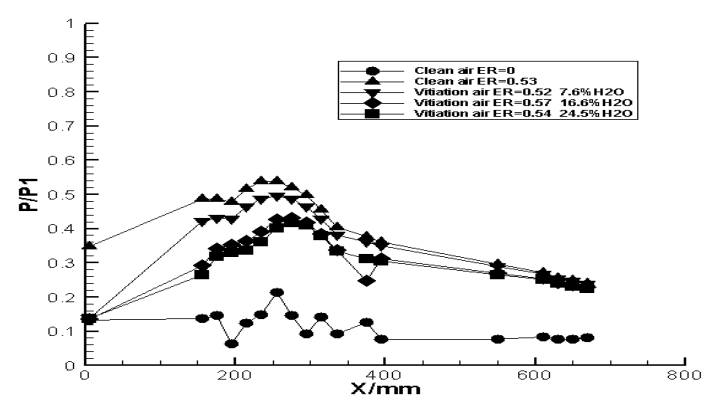

(a) Up-wall pressure

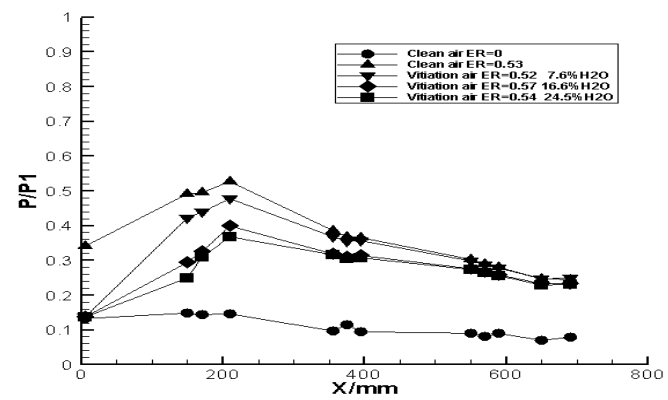

(b) Bottom-wall pressure

Figure 4. Comparison of the wall pressure

With increased mole fraction of $\mathrm{H}_{2} \mathrm{O}$ species vitiated air, from $0 \%, 7.6 \%, 16.6 \%$ to $24.5 \%$, the wall pressure of combustor were reduced. In climbed phase of wall pressure of combustor, the wall pressure were reduced extent about $10 \%$ to $18 \%$. After the cavity, the difference of wall pressure was inclined to decrease along axial of combustor. These showed: Because of $\mathrm{H}_{2} \mathrm{O}$ species introduced, the effect of species vitiated was very obviously on the highest wall pressure of combustor.

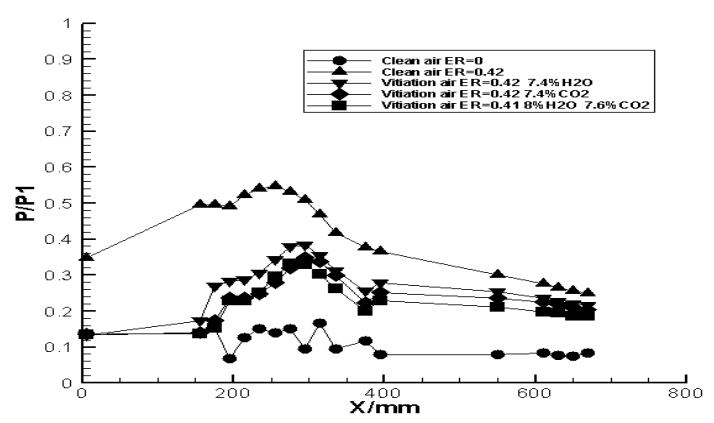

(a) up-wall pressure

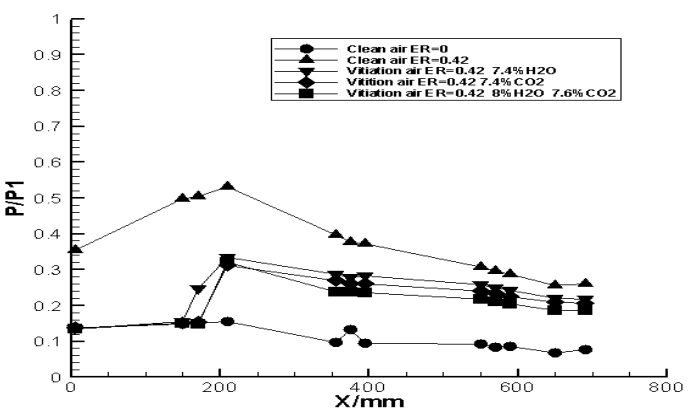

(b) bottom pressure

Figure 5. Comparison of the wall pressure

The combustion dimensionless up-wall and bottom pressure distribution of manifold $\mathrm{H}_{2} \mathrm{O}$ and $\mathrm{CO}_{2}$ species percent vitiated air was showed in the Figure 5, which species percent changed from $0 \%, 7.4 \% \mathrm{H}_{2} \mathrm{O}, 7.4 \% \mathrm{CO}_{2}$ to $8 \% \mathrm{H}_{2} \mathrm{O}+7.6 \% \mathrm{CO}_{2}$. As Fig5a, 5b showed, the highest wall pressure was clean air. The wall pressure of $7.4 \%$ $\mathrm{H}_{2} \mathrm{O}$ vitiated air was decreased about $18 \%$ than clean air. However, the wall pressure of $7.4 \% \mathrm{CO}_{2}$ vitiated air was lower than $7.4 \% \mathrm{H}_{2} \mathrm{O}$ vitiated air. It was lowest that the wall pressure of $8 \% \mathrm{H}_{2} \mathrm{O}+7.6 \% \mathrm{CO}_{2}$ vitiated air.

After the cavity, the difference of wall pressure was inclined to decrease along axial of combustor. For the hydrogen fuel, the wall pressure effect of $\mathrm{CO}_{2}$ species was higher than $\mathrm{H}_{2} \mathrm{O}$ species.

Table 3. The case of vitiated effect on the fuel ethylene with $\mathrm{H}_{2} \mathrm{O}$ and $\mathrm{CO}_{2}$

\begin{tabular}{cccc}
\hline Case & Contamination & $\Phi\left(\mathrm{C}_{2} \mathrm{H}_{4}\right)$ & Combustion status \\
\hline 3001 & Clean air & 0.58 & Steady \\
3002 & $\mathrm{H}_{2} \mathrm{O}: 7.8 \%$ & 0.56 & Steady \\
3003 & $\mathrm{H}_{2} \mathrm{O}: 8 \% ; \mathrm{CO}_{2}: 6.6 \%$ & 0.6 & Steady \\
\hline
\end{tabular}




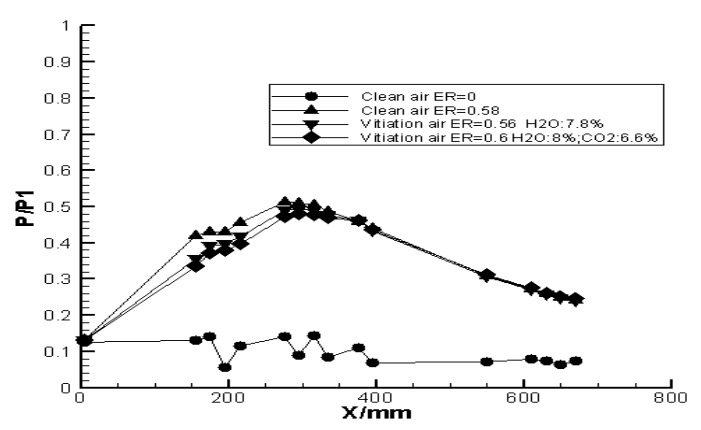

(a) up-wall pressure

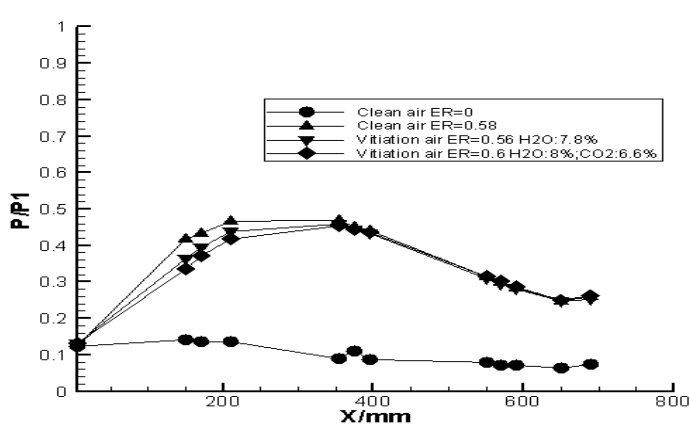

(b)bottom-wall pressure

Figure 6. Comparison of the wall pressure

In Figure 6, using ethylene fuel, the normalized up-wall and bottom pressure distribution of manifold species vitiated was showed respectively $0 \%, 7.8 \% \mathrm{H}_{2} \mathrm{O}$, and $8 \% \mathrm{H}_{2} \mathrm{O}+6.6 \% \mathrm{CO}_{2}$. As Figure $6 \mathrm{a}, 6 \mathrm{~b}$ showed, the wall pressure was increased and the top in the isolator and middle part of combustor. Then, the wall pressure was deceased with flow accelerated in the divergence part of combustor. The difference of wall pressure was obviously in pressure climbed phase, and the highest of wall pressure of combustor was clean air. With $7.8 \%$ $\mathrm{H}_{2} \mathrm{O}$ species vitiated air; the wall pressure of combustor was relatively lower than clean air. The lowest wall pressure was vitiated air with $8 \% \mathrm{H}_{2} \mathrm{O}+6.6 \% \mathrm{CO}_{2}$.

To compare front result of analyze, the conclusion was: the highest wall pressure of combustor was clean air for the airstream with manifold contaminated species. Furthermore, the wall pressure of combustor was deceased with contaminated species percent increased. The effect of $\mathrm{CO}_{2}$ contaminated species was more signally than $\mathrm{H}_{2} \mathrm{O}$.

The reason of pressure difference of combustor was multifarious. On the one hand, in the reaction of combustion $\mathrm{H}_{2} \mathrm{O}$ could be decomposed to the radical $\mathrm{H}, \mathrm{O}, \mathrm{OH}$, which would promote ignition and combustion. The $\mathrm{CO}_{2}$ was inertia in burnt reaction of hydrogen fuel. On the other hand, the difference of property of $\mathrm{H}_{2} \mathrm{O}$ and $\mathrm{CO}_{2}$ species introduced, some air species were altered by vitiated species, such as $\mathrm{N}_{2}, \mathrm{O}_{2}$, and then there was difference specific heat of clean and vitiated air. Integrated all complication, the $\mathrm{CO}_{2}$ species was showed signally effect on the combustor.

\section{Numerical Simulated}

The scramjet test carried through in the ground, limited by condition of test and measure instrument, couldn't acquire all the information of flow field and performance of scramjet of the effect of vitiated species. So the numerical simulated was needed to research the effect of vitiated species. The implicit expression and couple was applied to solve the two-dimension steady-state field. The turbulent mode of Realizable k- $\varepsilon$ was applied, used second order upwind and standard wall function. Meantime, the effect of variable specific heat was considered.

\subsection{Numerical Method Verify}

The numerical method was needed to verify, in order to simulate flow field true. Choose the case 1001 as test case to compare with the result of numerical. The initial condition was given in the Table 4 .

Table 4. The parameter of flow and fuel

\begin{tabular}{lllllll}
\hline Case & Mach number & $\mathrm{Pt}(\mathrm{Pa})$ & $\mathrm{Tt}(\mathrm{K})$ & $\mathrm{ER}(\mathrm{H} 2)$ & \multicolumn{2}{l}{ Flow species } \\
\hline 1001 & 2 & 750000 & 799 & 0.53 & $\mathrm{O}_{2}: 0.233$ & $\mathrm{~N}_{2}: 0.767$ \\
\hline
\end{tabular}




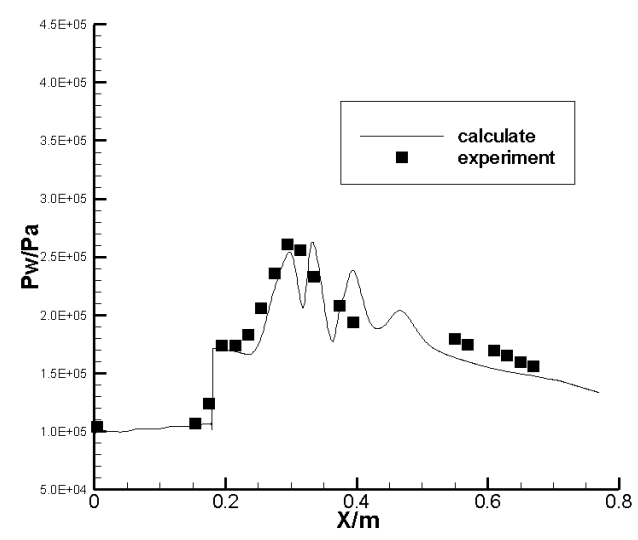

Figure 7(a). Up-wall pressure compare

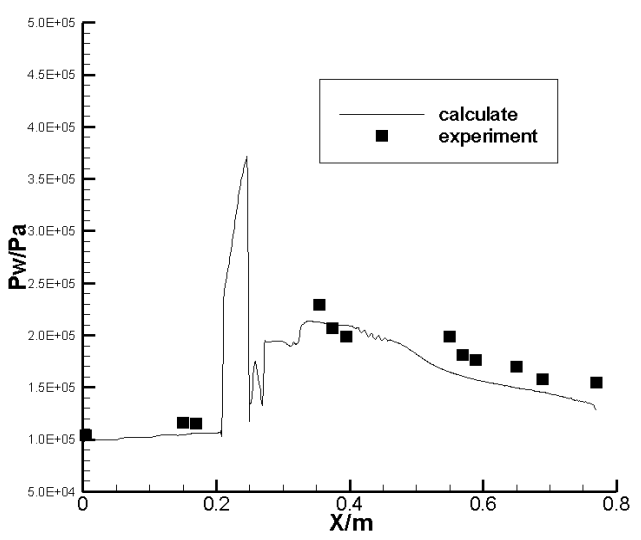

Figure 7(b). Bottom-wall pressure compare

It was discovery consistent that the result of test and numerical from Figure 7(a) and Figure 7(b). So the numerical method could be used to simulate the flow field of scramjet.

\subsection{Combustor Model and the Numerical Simulate Test Case}

The combustor model applied to numerical simulate was showed in Figure 1. The test cases of numerical simulate were given in Table 5.

Table 5. The parameter of flow and fuel

\begin{tabular}{lllll}
\hline Case & $\mathrm{Tt}$ & $\mathrm{Pt}$ & $\mathrm{ER}(\mathrm{H} 2)$ & Flow species \\
\hline 2001 & $786 \mathrm{~K}$ & $795 \mathrm{KPa}$ & 0.425 & $\mathrm{O}_{2}: 0.21 ; \mathrm{N}_{2}: 0.79 ; \mathrm{H}_{2} \mathrm{O}: 0 ; \mathrm{CO}_{2}: 0$ \\
2002 & $781 \mathrm{~K}$ & $756 \mathrm{KPa}$ & 0.42 & $\mathrm{O}_{2}: 21 ; \mathrm{N}_{2}: 0.715 ; \mathrm{H}_{2} \mathrm{O}: 0.074 ; \mathrm{CO}_{2}: 0 ;$ \\
2003 & $794 \mathrm{~K}$ & $790 \mathrm{KPa}$ & 0.423 & $\mathrm{O}_{2}: 0.217 ; \mathrm{N}_{2}: 0.627 ; \mathrm{H}_{2} \mathrm{O}: 0.08 ; \mathrm{CO}_{2}: 0.076$ \\
2004 & $807 \mathrm{~K}$ & $768 \mathrm{KPa}$ & 0.423 & $\mathrm{O}_{2}: 0.21 ; \mathrm{N}_{2}: 0.716 ; \mathrm{H}_{2} \mathrm{O}: 0 ; \mathrm{CO}_{2}: 0.074$ \\
2005 & $798 \mathrm{~K}$ & $765 \mathrm{KPa}$ & 0.425 & $\mathrm{O}_{2}: 0.202 ; \mathrm{N}_{2}: 0.615 ; \mathrm{H}_{2} \mathrm{O}: 0.183 ; \mathrm{CO}_{2}: 0$ \\
\hline
\end{tabular}

4.3 The Result Analyzed and Discussed

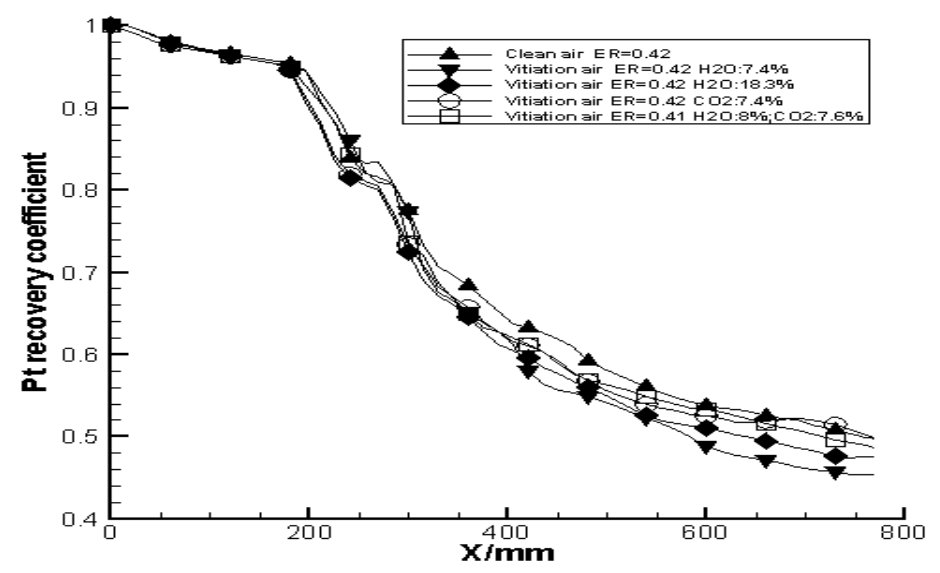

Figure 8 . Total pressure recovery coefficient 


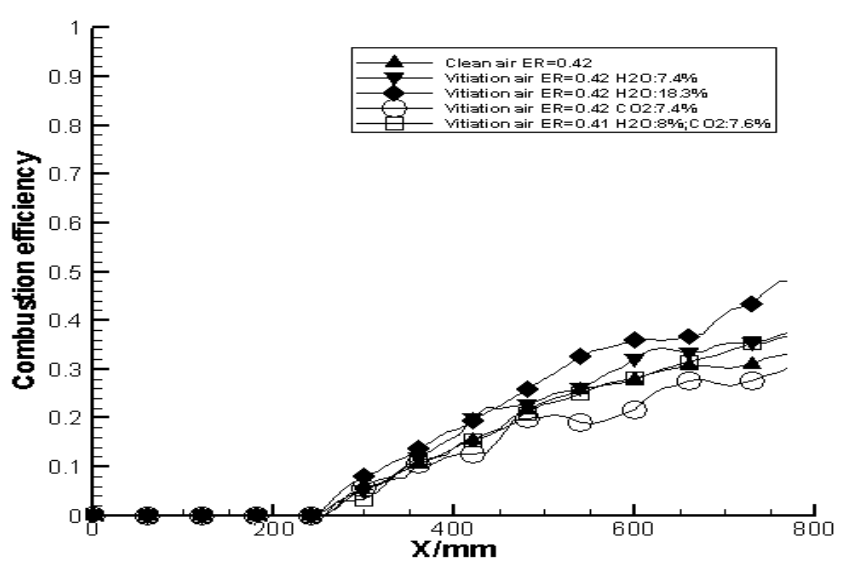

Figure 9. Combustion efficiency

In Figure 8, the total pressure recovery coefficients were compared. The highest value of coefficient was clean air, and the lowest of value of coefficient was the flow with $7.4 \% \mathrm{H}_{2} \mathrm{O}$ of vitiated species. The result of the flow with $7.4 \% \mathrm{CO}_{2}$ and $8 \% \mathrm{H}_{2} \mathrm{O}+7.6 \% \mathrm{CO}_{2}$ was in middle. By Figure 8 and Figure 9, the highest of combustion efficiency was the flow with $18.3 \% \mathrm{H}_{2} \mathrm{O}$ of vitiated species. It was explained that the efficiency was calculated used the total temperature. Meanwhile, that showed the present vapor and cracked $\mathrm{H}, \mathrm{O}, \mathrm{OH}$ promoted combustion. The lowest combustion coefficient was the coming flow with $7.4 \% \mathrm{CO} 2$, and the combustion coefficient of flow with $8 \% \mathrm{H}_{2} \mathrm{O}+7.6 \% \mathrm{CO}_{2}$ was higher than the flow with $7.4 \% \mathrm{CO}_{2}$. That showed the present $\mathrm{CO}_{2}$ could suppress combustion and decrease the performance of combustor. Considering Fig8 and Figure 9, that was concluded: the major role of vapor cracked $\mathrm{H}, \mathrm{O}, \mathrm{OH}$ was promoted combustion in scramjet and the present of $\mathrm{CO}_{2}$ could suppress combustion, respectively.

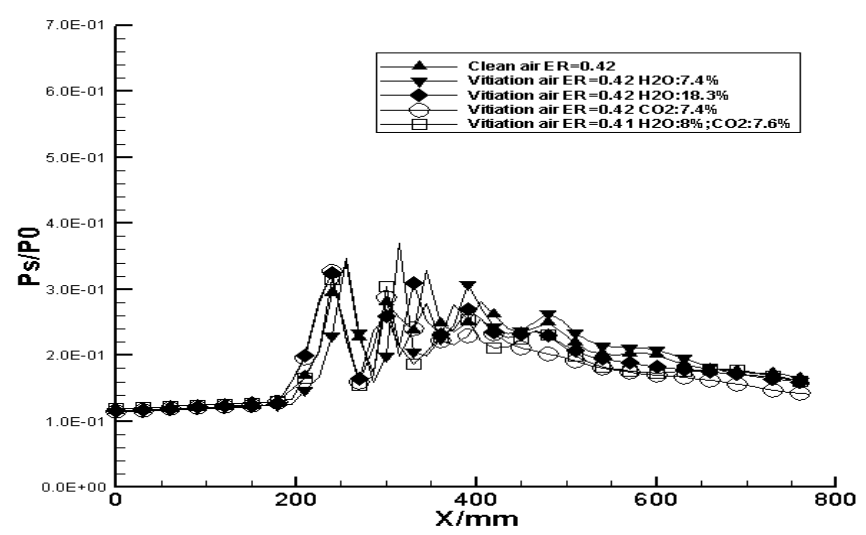

Figure 10. Axial static pressure

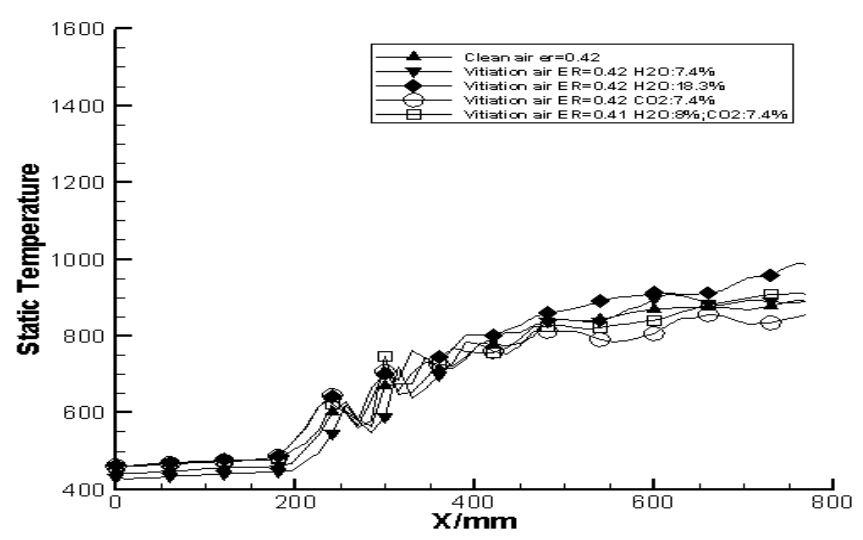

Figure 11. Axial static pressure 
In Figure 10, the axial averaged pressure of combustion was compared. The highest averaged pressure was the flow with $7.4 \% \mathrm{H}_{2} \mathrm{O}$, and the pressure of flow with $7.4 \% \mathrm{CO}_{2}$ was the lowest. That showed that the certainly present of vapor in the coming flow was positive for the combustion in scramjet. In Figure 11, the axial averaged temperature of combustion was compared. The highest averaged temperature was the flow with $18.3 \% \mathrm{H}_{2} \mathrm{O}$, and the temperature of flow with $7.4 \% \mathrm{CO}_{2}$ was the lowest. That could explain the coming flow with $18.3 \% \mathrm{H}_{2} \mathrm{O}$ taken more caloric joined action than other states. Considering Figure 10 and Figure 11, the thrust of scramjet could be influenced by the flow with the vitiated species, so the effect of vitiated species needed to be considered when the combustion was design.

\section{Conclusion}

In this article, the vitiated species was simulated to apply addition vitiated species to gas of nozzle exit of direct-connected resistance heated wind tunnel. The effect of vitiated species on the supersonic combustor was investigated used the fuel of hydrogen and ethylene, with $\mathrm{H}_{2} \mathrm{O}(7.4 \%, 7.6 \%, 7.8 \%, 16.6 \%, 24.5 \%)$ and $\mathrm{CO}_{2}$ $(7.4 \%, 7.6 \%)$ vitiated species, respectively. Then CFD simulations of reacting flow field in the combustor were conducted to investigate the effect of vitiated species of $\mathrm{H}_{2} \mathrm{O}$ and $\mathrm{CO}_{2}$ on the performance of supersonic combustor.

1. The highest wall-pressure of combustion was clean air. The wall-pressure of combustion was decreased with mole fraction of $\mathrm{H}_{2} \mathrm{O}$ increased from $0 \%, 7.6 \%, 16.6 \%$ to $24.5 \%$, pressure decreased markedly in phase of pressure climbed.

2. The combustion dimensionless up-wall and bottom pressure distribution of manifold mole fraction of $\mathrm{H}_{2} \mathrm{O}$ and $\mathrm{CO}_{2}$ species was compared, which mole fraction changed from $0 \%, 7.4 \% \mathrm{H}_{2} \mathrm{O}, 7.4 \% \mathrm{CO}_{2}$ to $8 \% \mathrm{H}_{2} \mathrm{O}+7.6 \% \mathrm{CO}_{2}$. The wall pressure of $7.4 \% \mathrm{H}_{2} \mathrm{O}$ vitiated air was decreased about $18 \%$ than clean air. However, the wall pressure of $7.4 \% \mathrm{CO}_{2}$ vitiated air was lower than $7.4 \% \mathrm{H}_{2} \mathrm{O}$ vitiated air. It was lowest that the wall pressure of $8 \%$ $\mathrm{H}_{2} \mathrm{O}+7.6 \% \mathrm{CO}_{2}$ vitiated air.

3. The performance of scramjet combustor was compared by numerical analyzed, the coming flow contained vitiated air with mole fraction of $7.4 \% \mathrm{H}_{2} \mathrm{O}, 18.3 \% \mathrm{H}_{2} \mathrm{O}, 7.4 \% \mathrm{CO}_{2}$ and $8 \% \mathrm{H}_{2} \mathrm{O}+7.6 \% \mathrm{CO}_{2}$. The result was the thrust of scramjet could be influenced by the flow with the vitiated species, so the effect of vitiated species couldn't be ignored when the combustion design.

Summarized the result of experiment and numerical, the performance of combustor could be effected by vitiated species, and the evaluation of the performance of scramjet was influenced because of altered performance.

\section{References}

Boyce, R. R., Wendt, M., Puall, A., Chinzei, N., Stalker, R. J., \& Miyajima, H. (1998). Supersonic combustion-a shock tunnel and vitiation-heated blowdown tunnel comparison. AIAA, 1998-0914.

Goyne, C. P., McDaniel, Jr. J. C., Krauss, R. H., \& Whitehurst, W. B. (2007). Test gas vitiation effects in a dual-mode scramjet combustor. Journal of Propulsion and Power, 23(3), 559-565. http://dx.doi.org/10.2514/1.24663

Hou, L. Y., Yang, J., Ma, X. S., \& Liu, W. (2010). Effects of Species in Vitiation Air on Methane-Fueled Supersonic Combustion. Acta Physico-Chimica Sinica, 26(12), 3150-3156. http://dx.doi.org/10.3866/PKU.WHXB20101204

Huebner, L. D., Rock, K. E., Voland, R. T., \& Wieting, A. R. (1996). Calibration of the Langley 8-Foot High Temperature Tunnel for Hypersonic Airbreathing Propulsion Testing. 19th AIAA Advanced Measurement and Ground Testing Technology Conference, New Orleans, LA, AIAA, 96-2197.

McDaniel Jr, J. C., Krauss, R. H., Whitehurst, W. B., \& Goyne, C. P. (2003). Test gas vitiation effects in a dual-mode combustor. AIAA, 2003-6960.

Mitani, T., Hiraiwa, T., Sato, S., Tomioka, S., Kanda, K., Saito, T., ... Tani, K. (1996). Scramjet engine testing in mach 6 vitiated air. AIAA, 1996-4555.

Mitani, T., Hiraiwa, T., Sato, S., Kanda, K., \& Tani, K. (1997). Comparison of scramjet engine performance in Mach 6 vitiated and storage-heated air. J. Propulsion and Power, 13(5).

Liu, L., Tang, M., Zhang, Z., Liu, J. H., Wang, Y. R., \& Yang, L. X. (1992). Effects of vitiated air on the results of ground tests of scramjet combustor. Journal of Propulsion Technology, 5.

Liu, W. X., Yang, Y., Shao, J. X., Song, W. Y., Li, X. Y., \& Le, J. L. (2009). Influence of $\mathrm{H}_{2} \mathrm{O}$ and $\mathrm{CO}_{2}$ Contamination in Air on the Combustion Properties of Ethylene. Acta Physico-Chimica Sinica, 25(8), 
1618-1622.

Rogers, R. C. (1986). Effects of Test Facility Contaminants on Supersonic Hydrogen-Air Diffusion Flames. $23^{\text {rd }}$ JANNAF Combustion Meeting, Hampton, VA.

Song, W. Y., Wang, D., Chen, L., \& Le, J. L. (2007). Experimental facility and preliminary results for supersonic combustion in clean air inflow. Experiments and Measur in fluid Mechanics, 21(1).

Voland, R. T., Auslender, A. H., Smart, M. K., Roudakov, A. S., Semenov, V. L., \& Kopchenov, V. (1999). GIAM/NASA mach 6.5 scramjet flight and ground test. AIAA, 99-4848. 